\title{
The expression BIRC6 gene in patients with chronic lymphocytic leukemia - a preliminary study
}

\author{
Piotr Chomik ${ }^{1}$, Paulina Gil-Kulik ${ }^{1}$, Malgorzata Filas ${ }^{1}$, Agnieszka Wojcieszek ${ }^{1}$, \\ Mateusz Wilinski ${ }^{1}$, Jolanta Karwat ${ }^{1}$, Lidia Kotula ${ }^{1}$, Alicja Niedojadlo ${ }^{1}$, Marcin Czop ${ }^{1}$, \\ Anna Bogucka-Kocka ${ }^{2}$, Maria Cioch ${ }^{3}$, Ryszard Pluta ${ }^{4}$, Janusz Kocki ${ }^{1 *}$ \\ ${ }^{1}$ Department of Clinical Genetics, Medical University of Lublin, 11 Radziwillowska, 20-080 Lublin, Poland \\ ${ }^{2}$ Department of Pharmaceutical Botany, Medical University of Lublin, Poland \\ ${ }^{3}$ Department of Haematology and Bone Marrow Transplantation, Medical University of Lublin, Poland \\ ${ }^{4}$ Laboratory of Ischemic and Neurodegenerative Brain Research, Mossakowski Medical Research Centre, Polish Academy of Sciences, \\ Warsaw, Poland
}

\begin{tabular}{l}
\hline ARTICLE INFO \\
\hline Received 19 September 2014 \\
Accepted 7 November 2014 \\
\hline
\end{tabular}

\section{Keywords:}

apoptosis,

BIRC6 gene,

Apollon,

Bruce,

CLL,

chronic lymphocytic leukemia.

\begin{abstract}
The BIRC6 gene encodes the Bruce (Apollon) protein. This belongs to the III class of Inhibitors of the Apoptosis Protein (IAP) and demonstrates anti-apoptotic activity (binding, inhibiting and degrading the caspases). Moreover, the Bruce protein shows multilevel activities and additional functions. The Bruce protein is involved in the maintenance of cell viability, and it is also suggested that it plays an important role in cell proliferation and diversification. Many researchers have noticed elevated BIRC6 gene expression in cell lines of brain cancer and ovarian carcinoma, leukemia, breast cancer and even in colorectal cancer tissues. Resistance to chemotherapy-inducted apoptosis in cancers characterized by BIRC6 gene over-expression was also reported. The aim of the study was to assess the BIRC6 gene expression in peripheral blood lymphocytes of patients diagnosed with chronic lymphocytic leukemia.
\end{abstract}

\section{INTRODUCTION}

Neoplastic diseases are the second leading cause of human death in the modern world (right after cardiovascular diseases). This high mortality rate is very often brought about by too late or wrong disease diagnosis or by inefficient treatment. Disorders of balance between cell proliferation and their susceptibility to apoptosis have a great significance in neoplastic diseases development.

Chronic lymphocytic leukemia (CLL) is a clonal lymphoproliferative disorder in which apoptosis is inhibited in morphologically mature but functionally faulty B lymphocytes. It brings about an observed over-accumulation of lymphocytes, which in turn infiltrate the bone marrow, lymph nodes, spleen and other organs. Probably, the main defects underlying the pathogenesis of CLL are certain abnormal regulatory mechanisms of apoptosis, leading to the inhibition and to the formation of the leukemic clone. Leukemic cells are characterized by the expression of B-cell CD23 and CD19, the low expression of CD79b and CD 20,

\section{Corresponding author}

tel: +48814486110 , the presence of $\operatorname{IgM}$ and IgD surface immunoglobulins and $\kappa$ or $\lambda$ light chains, as well as the co-expression of the CD 5 antigen T-cell line. However, usually cyclin D1, CD10 antigen and FMC7 are not expressed [8,15, and 16].

Apoptosis is physiological cell death. This process is strictly regulated on many levels by many pro- and antiapoptotic proteins. The Bcl-2 and p53 protein families and the IAP protein family inhibitors of apoptosis play fundamental roles in apoptosis. Cancer cells, however, have many protection mechanisms with regard to apoptosis, and Cancer transformation leads to over-expression of inhibiting apoptosis factors or to a reduction of activating apoptosis factors expression [4,7,9,14,20, and 26]. IAP proteins are polypeptide inhibitors of apoptosis [6,24,29]. In most cases, IAP proteins are capable of directly binding to, and, hence, inhibiting the caspases, thus not allowing the enzyme activation and blocking process of apoptosis. Some IAP proteins take part in cell cycle regulation and intracellular signal transduction, acting as ubiquitin ligases, which induce the degradation of caspases [4,9,23,28, and 31]. There are many reports regarding elevated IAP proteins expression in 
noeplastic diseases, especially in acute myeloid leukemia and myelodysplastic syndrome [30]. In addition, elevated survivin expression (a member of IAP family) was reported in prostatic carcinoma, stomach cancer, breast cancer, acute leukemia and brain cancer $[4,9,13,14,19$, and 24]. The role of IAP proteins and their antagonists in the regulation of cell death suggests that they may take part in neoplastic disease development. Over-expression of IAP proteins or decreased antagonists expression is a result of a genetic defect and may lead to "anti-apoptotic profile" cell creation, facilitating the proliferation of neoplasmic clones [4,9,14, 23, and 19].

The BIRC6 gene (Baculoviral IAP-repeat-containing $\sigma)$ is also known as Apollon and Bruce. It is localized at the chromosome 2 (2p22.3), and is comprised of 75 exons, resulting in a transcript of $16066 \mathrm{bps}$. This gene encodes the Bruce protein, which belongs to the III class of IAPs. The Bruce protein is a big membrane protein $(528 \mathrm{kDa})$ and is made up of 4857 amino acids. Bruce is a conservative evolution protein and is located on the trans Golgi apparatus network. It is characterized by the presence of one BIR domain and the absence of a RZF motif. On its C-terminal, there is E2-domain UBC enzyme which is capable of ubiquitin binding. This suggests that the Bruce protein may act as an E3 ubiquitin ligase [2,5 and 34].

Available literature suggests that the Bruce protein has anti-apoptotic activity [2,22 and 32], and inhibits caspases via the BIR domain. Furthermore, it acts as a chimeric E2/ E3 enzyme and causes ubiquitination and proteasomal degradation of the Smac protein and its precursor. It affects caspase- 9 and procaspase- 9 in the same manner (binding its transformation into an active form) [2,5,22 and 32]. While Bruce also ubiquitylates and facilitates Htra2 proteasomal degradation, HtrA2 has the ability to decompose the catalytic Bruce protein. Hence, the Bruce protein and HtrA2 decrease the expression of each other, the degree of the effect of Bruce-HtrA2 interaction being dependent on the relative levels of these proteins [33].

Smac and HtrA2 are pro-apoptotic proteins, and they minimise caspases inhibition via IAPs. These proteins are synthesized in form of huge cytosolic precursors, and undergo proteolytic transformation into mature protein forms. Their mature forms have IBM domains which bind inhibitory apoptosis proteins. Reacting to signals of cell death, mature Smac and HtrA2 proteins are released into the cytosol and interact with IAPs [9,23,24,29 and 19].

Procaspase-9, via the creation complex with Apaf-2, has an important role in caspases activation because the interaction between Bruce and procaspase- 9 inhibits caspases. Moreover, it is resistant to other IAPs activities [32].

The Bruce protein is not fully understood. It shows multilevel activities, and, according to available literature, apart from its anti-apoptotic activities (binding, inhibiting and degrading caspases), it has other functions. It has been reported that the Bruce protein is involved in maintenance of cell viability. It is also suggested that it plays an important role in proliferation processes and cell diversification [2,18,21,22 and 25].

\section{AIM OF STUDY}

The aim of the study was to assess the gene expression of Class III IAPs BIRC6 in the peripheral blood mononuclear cells (PBMCs) of patients diagnosed with chronic lymphocytic leukemia, and in normal peripheral blood mononuclear cells.

\section{MATERIAL}

The study was carried out on mononuclear cells of peripheral blood taken from twenty-two individuals at the Chair and Department of Haematooncology and Bone Marrow Transplantation in Lublin. All tested subjects were diagnosed with chronic lymphocytic leukemia, and the tested group of patients consisted of twelve patients ( 5 women and 7 men). The process of taking and analyzing the material was performed in accordance with the study protocol approved by the Bioethical Commission and Head of the Clinic. The control group consisted of mononuclear cells of peripheral blood taken from ten healthy people without leukemia.

\section{METHODS}

The mononuclear cells were isolated from whole blood using the band centrifugation technique, with the use of the Percol reagent. The analysis was carried out in the RNA samples obtained from the mononuclear cells. The isolation of the complete cellular RNA from cells was carried out using the modified Chomczyński and Sacchi method, with the use of the TRI-Reagent (Sigma). The specific fragment of the analysed gene was obtained through amplification with the use of cDNA synthesised in the reaction of reverse transcription, according to manufacturers protocol, use reagents High-Capacity cDNA Transcription Kits (Applied Biosystems). The analysis of expression was conducted using the Real-Time PCR method, with the use of the AppliedBiosystems StepOnePlus System. In the analysed cases, the level of expression of the BIRC6 gene (Hs00212288_m1) was compared to the level of expression of the GAPDH reference gene (Hs99999905_m1) that was amplified in the same amount of RNA isolated from the same cells.

\section{RESULTS}

The gene expression analysis was conducted using the ExpressionSuite Software v.1.0.3; the results are presented in Fig. 1 and Fig.2. The average relative BIRC6 gene expression in the group of patients suffering from chronic lymphocytic leukemia was 5.371. The highest average BIRC6 expression was recorded in the LLC09 test and it amounted to 45.001. The lowest relative expression BIRC6 gene was recorded in the LLC11 test, and it amounted to 1.693.

The highest expression of BIRC6 gene was detected in a patient with CLL, refractory to two lines of chemotherapy (fludarabine+ cycophosphamide and bendamustine). Two other patients with relatively high BIRC6 expression are characterized by having both a high WBC count $(>$ $100.0 \times 10^{\wedge} 9 / \mathrm{L}$ ) and anemia (autoimmune in one of these cases). The presence of the two conditions allows the 
classification of these patients to stage 3 , according to the Rai classification of CLL.

The study showed that the mRNA of the BIRC6 gene is present in the cells of the patients suffering from chronic lymphocytic leukemia, as well as in the cells of healthy individuals. In all cases, the mononuclear cells taken from the patients suffering from chronic lymphocytic leukemia were characterized by increased gene expression, in comparison to the normal cells drawn from healthy people. Of note, in the LLC05 test, the result showing the BIRC6 gene expression was not reported.

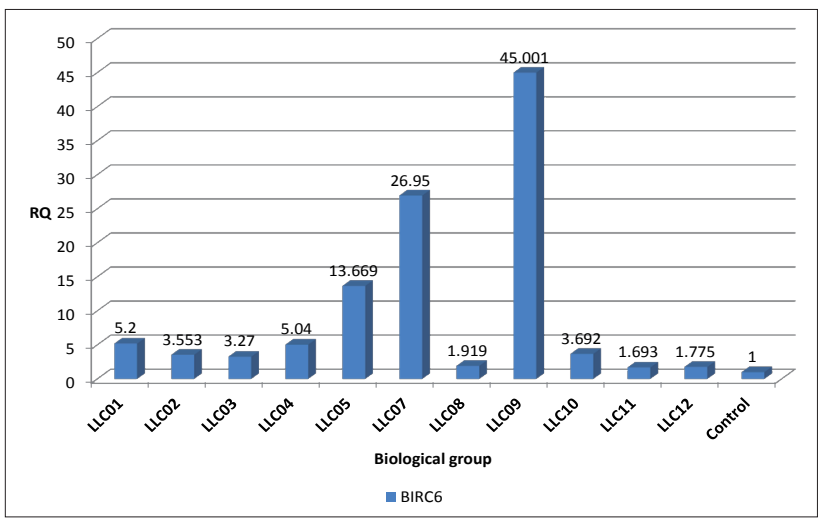

Figure 1. Relative BIRC6 gene expression in peripheral blood mononuclear cells of patients with chronic lymphocytic leukemia. Calibrator - control group (BIRC6 gene expression in peripheral blood mononuclear cells of individuals free of leukemia)

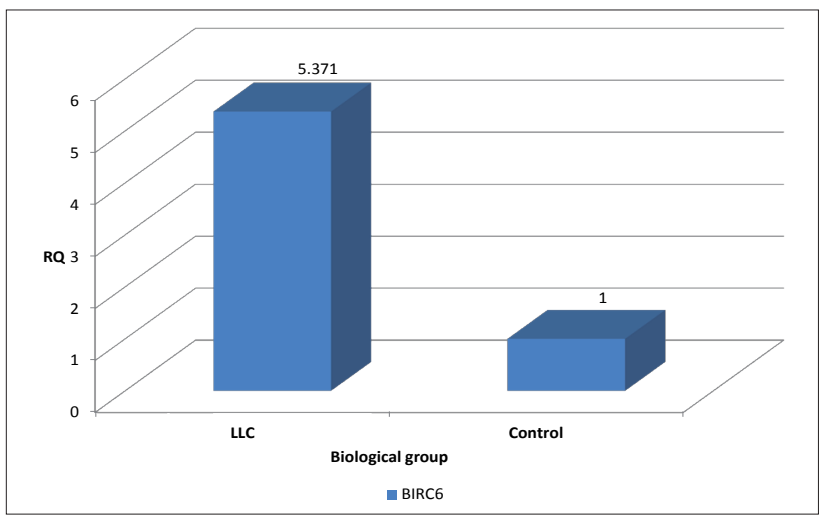

Figure 2. The average relative BIRC6 gene expression in the group of patients suffering from chronic lymphocytic leukemia. Calibrator - control group

Enhanced BIRC6 gene expression in the mononuclear cells of patients with leukemia can suggest the presence of an increased amount of the inhibitor protein Bruce, and also the decreased sensitivity of cells to apoptosis. Many researchers have noticed elevated BIRC6 gene expression in cell lines of brain cancer and ovarian carcinoma, leukemia, breast cancer and even in colorectal cancer tissues. Moreover, resistance to chemotherapy-inducted apoptosis in cancers that are characterized by BIRC6 gene over-expression, has also been reported [1,3,5, and 17]. The regulation of Bruce protein expression plays an important role in apoptosis, as an increase or decrease in this protein expression changes the cell susceptibility to a death stimulus. Thus, understanding BIRC6 gene expression is perceived as being a new therapeutic aim in the treatment of malignancies characterized by its over-expression [24,17].

Guo Sung and Ismail researched BIRC6 gene expression, as well as Bruce protein expression in acute leukemias [11, $22,27]$. They discovered that Bruce protein expression in patients with acute leukemias was much higher, in comparison to a control group [11]. The authors suggest that BIRC6 gene over-expression is connected with an ineffective response to treatment and to a shorter progression-free survival. In their work, they pointed out the possible predictive meaning of the BIRC6 gene [27]. Furthermore, they suggest that BIRC6 gene expression may be recognized as a risk factor in children with acute leukemia [12]. Abe et al. also revealed a much higher mRNA BIRC6 expression in marrow cells with MDS, in comparison to normal cells. They noted that, at the same time, this expression decreased after transformation into acute myeloid leukemia. It should be noted that cells with de novo acute myeloid leukemia are characterized by higher BIRC6 gene expression, in comparison to cells belonging to MDS [1].

Recent researches show heightened interest in the BIRC6 gene, and its possible influence on neoplastic diseases formation and development is being analysed. Indeed, many researchers are now attempting to estimate the BIRC6 gene involvement in cell resistance to treatment-inducted apoptosis. In addition, such researchers are focusing on the possible chance of employing BRIC6 gene in targeted therapy.

\section{CONCLUSIONS}

Further researches on BIRC6 gene expression allow us to broaden our knowledge of its involvement in carcinogenesis. The high BIRC6 expression in patients with CLL in an advanced stage, in addition to its refractory effect upon chemotherapy, suggests its negative role in prognosis. What is more, previous experiences has shown that the BIRC6 gene, in connection with Bruce cystostatics and inhibitors, may be used in designing new anticancer therapies. Literature and conducted researches also show BIRC6 gene involvement in neoplastic diseases.

\section{ACKNOWLEDGEMENTS}

This study was supported by founds from Mossakowski Medical Research Centre, Polish Academy of Sciences (T4 RP) and Polish Ministry of Science and Higher Education (project NN 405162639). The paper was developed using the equipment purchased within the Project "The equipment of innovative laboratories doing research on new medicines used in the therapy of civilization and neoplastic diseases" within the Operational Program Development of Eastern Poland 2007-2013, Priority Axis I Modern Economy, Operations I.3 Innovation Promotion.

\section{REFERENCES}

1. Abe S. et al.: Bone marrow cells of mieloblastic syndromes exhibit significant expression of apollon, livin and ILP-2 with reduction after transformation to overt leukemia. Leukaemia Research 2005; 29: 1095-1096.

2. Bartke T. et al.:Dual role of BRUCE as an antiapoptotic IAP and a chimeric E2/E3 ubiquitin ligasz. Md Cell 2004; 14: 801-811. 
3. Bianchini M. et al.: Comparative study of gene expression by cDNA microarray in human colorectal cancer tissues and normal mucosa. Int J Oncol. 2006; 29: 83-94.

4. Bielak-Żmijewska A.: Mechanizmy oporności komórek nowotworowych na apoptozę. Problemy Nauk Biologicznych. Kosmos 2003; 52: 157-171.

5. Chen Z. et al.: A human IAP-family gene, apollon, expressed in human brain cancer cells. Biochem Biophys Res Commun. 1999; 264: 847-854.

6. Deveraux Q.L., Reed J.C.: IAP family proteins suppressor of apoptosis. Genes Dev. 1999; 13: 239-252.

7. Ghavami S. et al.: Apoptosis and cancer: mutations within caspase. J Med Genet 2009; 46: 497-510.

8. Giannopoulos K.: Biologia i rokowanie w przewlekłej białaczce limfocytowej. Acta Haematologica Polonica 2010; 3: 433-440.

9. Grzybowska-Izydorczyk O., Smolewski P.: Białka inhibitorowe apoptozy z rodziny inhibitorów apoptozy (IAP) i ich antagoniści: rola biologiczna oraz potencjalne znaczenie w karcinogenezie i celowanej terapii przeciwnowotworowej. Acta Haematologica Polonica 2009; 40: 593-612.

10. Grzybowska-Izydorczyk O., Smolewski P.: Rola białek z rodziny inhibitora apoptozy (IAP) w chorobach rozrostowych układu krwiotwórczego. Postępy Hig Med. Dosw. 2008; 62: 55-63.

11. Guo J. et al.: A preliminary study on the implication of Apaf-1 promoter methylation and the expression of apoptosis inhibitor protein Apollon in adult acute leukaemia. Zhonghua Xue Ye Xue Za Zhi. 2010; 31: 736-739.

12. Ismail EA. Et al.: BIRC6/Apollon gene expression in childhood acute leukemia: impact on therapeutic response and prognosis. Eur J Haematol. 2012; 88:118-27. [53]

13. Kaczmarek-Borowska B., Zmorzyński Sz., Filip A.: Biologiczna rola surwiwiny. Współczesna onkologia 2008; 10: 437-440.

14. Korzeniowska-Dyl I.: Kaspazy - struktura i funkcja. Pol. Merk. Lek. 2007; 138: 403-407.

15. Krawczyk-Kuliś M et al.: Nowe markery prognostyczne przewlekłej białaczki limfocytowej badane metodą immunofenotypizacji. Acta Haematologica Polonica 2012; 3: 271-276.

16. Lewandowski K, Matuszak M.: Czynniki prognostyczne w przewlekłej białaczce limfatycznej B-komórkowej. Współczesna Onkologia, 2003; 7:470-475.

17. Lopergolo A. et al.: Apollon gene silencing induces apoptosis in breast cancer cells through p53 stabilisation and caspase- 3 activation. Journal List 2009; 100: 739-746.

18. Lotz K., Pyrowolakis G., Jentsch S.: BRUCE, a gigant E2/E3 ubiquitin ligase and inhibitor of apoptosis protein of the trans - Golgi network, is required for normal placenta development and mouse survival. Mol Cell Biol. 2004; 24: 9339-9350.
19. Malinowska I.: Rola apoptozy w patogenezie i leczeniu nowotwór układu hematopoetycznego. Postępy Hig Med. Dosw. 2004; 58: 548-559.

20. Mitrus I., Missot-Kolka E., Szala S.: Geny proapoptotyczne w terapii genowej nowotworów. Współczesna onkologia 2001; 5: 242-249.

21. Pohl C., Jentsch S.: Final stages of cytokinesis and mid-body ring formation are controlled by BRUCE. Cell 2008; 132: 832-845.

22. Qiu X.B. et al.: Nrdpl-mediated degradation of the gigantic IAP, BRUCE, is a novel pathway for triggering apoptosis. EMBO J. 2004; 23: $800-810$.

23. Rumble J.M., Duckett C.S.: Diverse function within the IAP family. Journal of Cell Science 2008; 121: 3505-3507.

24. Rupniewska Z., Koczkodaj D., Wąsik-Szczepanek E.: BRUCE/ Apollon i jego rola w rodzinie białek hamujących apoptozę. Acta Haematologica Polonica 2006; 37: 329-337.

25. Salilew-Wondim D et al.:. Depletion of BIRC6 leads to retarded bovine early embryonic development and blastocyst formation in vitro. Reprod Fertil Dev. 2010; 22: 564-79.

26. Stańczyk M., Majsterek I.: Apoptoza - cel ukierunkowanej terapii przeciwnowotworowej. Postępy Biologii Komórki, 2008; 35: 467-484.

27. Sung K.W. et al.: Over-expression of Apollon, an antiapoptotic protein is Associated with Poor Prognosis in Childhood De novo Acute Myeloid Leukemia. Clin CANCER Res. 2007; 13: 5109-5114.

28. Verhagen A.M., Coulson E.J., Vaux D.L.: Inhibitor of apoptosis proteins and their relatives: IAPs and other BIRPs. Genome Biology 2001; 2: 3009.1-3009.10.

29. Wright C.W., Duckett C.S.: Reawakening the cellular death program in neoplasia through the therapeutic blockade of IAP. J Clin Invest 2005; 115: 2673-2678.

30. Yamamoto K. et al.: Expression of IAP proteins in myelodysplastic syndromes trans forming to overt leukemia. Leukemia Research 2004; 28: 1203-1211.

31. Yang L.Y., Li X.M.: The IAP family: endogenous caspase inhibitors with multiple biological activities. Cell Research 2000; 10: 169-177.

32. Hao Y., Sekine K., Kawabata A., Nakamura H., Ishoika T., Ohata H., KatayamaR., Hashimoto C., Zhang X., Tsuro T., Kwaito M. Apollon ubiquitinates Smac and caspases-9 and has an essential cytoprotetion function. Nature Cell Biol 2004; 6: abstract.

33. Sekine K., Hao Y., Suzuki Y., Takahashi R., Tsuruo T., Natio M. HtrA2 cleaves Apollon and induces cell death by IAP-binding motif in Apollon-deficient cells. Biochem Biophys Res Commun. 2005; 330: abstract

34. Hauser H.P., Bardoff M., Pyrowolakis G., Jentsch S. A giant ubiquitin-conjugating enzyme related to IAP apoptosis inhibitors. J Cell Biol. 1998;141: abstract. 